\title{
Exposures and cancer incidence near oil fields in the Amazon basin of Ecuador
}

\author{
M San Sebastián, B Armstrong, J A Córdoba, C Stephens
}

\begin{abstract}
Objectives-To examine environmental exposure and incidence and mortality of cancer in the village of San Carlos surrounded by oil fields in the Amazon basin of Ecuador.

Methods-Water samples of the local streams were analyzed for total petroleum hydrocarbons (TPHs). A preliminary list of potential cancer cases from 1989 to 1998 was prepared. Cases were compared with expected numbers of cancer morbidity and mortality registrations from a Quito reference population.

Results-Water analysis showed severe exposure to TPHs by the residents. Ten patients with cancer were diagnosed while resident in the village of San Carlos. An overall excess for all types of cancer was found in the male population (8 observed $v 3.5$ expected) with a risk 2.26 times higher than expected $(95 \%$ confidence interval (95\% CI) 0.97 to 4.46$)$. There was an overall excess of deaths for all types of cancer ( $6 v 1.6$ expected) among the male population 3.6 times higher than the reference population ( $95 \%$ CI 1.31 to 7.81 ). Conclusions-The observed excess of cancer might be associated with the pollution of the environment by toxic contaminants coming from the oil production.

(Occup Environ Med 2001;58:517-522)
\end{abstract}

Keywords: cancer; oil; Amazon; Ecuador

The tropical forests of Ecuador are among the most biologically diverse natural ecosystems on earth, and are home to peasants and several indigenous groups. The Amazon also has hundreds of oil fields, the most important source of income in Ecuador. Since 1972, foreign oil companies, led by Texaco and Ecuador's national oil company, Petroecuador, have extracted more than two billion barrels of crude oil from the Ecuadorian Amazon. Currently, 13 companies are operating in the country: 1 private national, Petroecuador, and 11 foreign companies. Oil has been the lynchpin of the economy. The 1970s oil price boom lifted Ecuador from being one of the poorest countries in Latin America - per capita income rose from $\$ 290$ in 1972 to $\$ 1490$ in 1982 , decreasing to $\$ 1390$ in 1995 . Today, oil continues to account for nearly $50 \%$ of the nation's income from exports and government budget. However, in this development process, billions of gallons of untreated waste, gas, and crude oil have been released into the environment. ${ }^{1}$ There are potential problems of this process of development on the environment and the health of local people. We examined this issue.

Oil, environment, and health: the literature

Oil extraction involves several contaminating processes. Drilling wastes can typically contain considerable amounts of several drilling muds (used as lubricants and sealants), and a water mixture can be formed deep below the earth's surface that contains hydrocarbons, heavy metals, and high concentrations of salt. Burning oil and gas pollutes the air with oxides of nitrogen, sulphur, and carbon, as well as heavy metals, hydrocarbons, and soot (carbon particulate). ${ }^{2}$ Crude oil is a complex mixture of many chemical compounds, mostly hydrocarbons. The petroleum hydrocarbons of most toxicological interest are volatile organic compounds (benzene, xylene, and toluene) and polynuclear aromatic hydrocarbons (PAHs). ${ }^{3}$

Studies on mice have reported skin tumours after application of crude oil to the skin..$^{4-6}$ However, a review concluded that there is limited evidence showing carcinogenicity of crude oil in experimental animals, and also that there was inadequate evidence of carcinogenicity of crude oil in humans. ${ }^{3}$

Benzene is a well known cause of leukaemia, ${ }^{78}$ and perhaps other haematological neoplasms and disorders. ${ }^{9} 10$ No adequate data on the incidence of cancer after human exposure to the other volatile organic chemicals from oil exist. ${ }^{11}$ A population based case-control study carried out in Montreal showed limited evidence that increased risk was found for the following associations: oesophagus-toluene, colon-xylene, rectum-toluene, rectum-xylene, and rectum-styrene. ${ }^{12}$ An ecological study performed to examine the relation between the incidence of leukaemias and the occurrence of contamination of drinking water supplies by volatile organic chemicals (VOCs) suggested that VOCs might increase the incidence of leukaemia among exposed women. ${ }^{13}$ Different epidemiological studies have reported direct evidence of the carcinogenic effects of PAHs in occupationally exposed subjects. Strong evidence of carcinogenic effects of PAHs on the skin, bladder, and scrotum has been found. ${ }^{14-18}$ Workers in several industries with appreciable exposure to PAHs have also been shown to be at risk of lung cancer. ${ }^{15}$ 17-19

Few studies of risk of cancer among inhabitants of areas close to petrochemical industries have been reported. In the United States, an ecological study found an association in both sexes between residential exposure to petroleum and chemical emissions in air and cancer 
of the buccal cavity and pharynx. In men, age adjusted incidences of cancers of the stomach, lung, prostate, and kidney and urinary organs were also associated with exposures to petroleum and chemical plant emissions in air. ${ }^{20} \mathrm{~A}$ study in the same country found high rates of cancer of the lung, nasal cavity and sinuses, and skin among the resident male population. ${ }^{21}$ Other studies in the United States have suggested high rates of lung cancer and an increased risk of brain cancer among people living near petrochemical plants. ${ }^{22} 23$ Studies from the United States have also reported negative results. ${ }^{24}$

Childhood leukaemia and other childhood cancers have been geographically associated with industrial atmospheric effluent-for example with volatile compounds derived from petroleum in Great Britain. ${ }^{25}{ }^{26}$ By contrast, a study from Wales did not find an association between incidence of leukaemias and lymphomas in children and young people in the area around the BP Chemical site at Baglan Bay, South Wales. ${ }^{27} \mathrm{~A}$ recent report around all industrial complexes that include major oil refineries in Great Britain found no evidence of association between residence near oil refineries and leukaemias or non-Hodgkin's lymphoma. ${ }^{28}$

Studies conducted in Taiwan have reported an excess rate for liver and lung cancer ${ }^{29} 30$ and an excess of deaths from bone, brain, and bladder cancer in young adults associated with residence near petrochemical industries. ${ }^{31}$

Few studies have been conducted in petroleum exploration and production workers. In one of two case-control studies, an excess risk for testicular cancer was found among petroleum and natural gas extraction workers. ${ }^{32}$ No such excess was found in the other study. ${ }^{33}$ In a case-control study of cancer at many sites, an association was found between exposure to crude oil and rectal and lung cancer, however, the association was based on small numbers. ${ }^{34}$ A study carried out on production and pipeline workers in the United States did not find significant differences for any major cause of death. ${ }^{35}$ Sathiakumar et $a b^{36}$ conducted an epidemiological study in oil and gas field workers in the United States that showed a positive association between work and acute myelogenous leukaemia. A study from China has also reported high incidences of leukaemia in oil field workers. ${ }^{37}$

Although several studies have focused on health effects of major oil spillages, ${ }^{11} 3839$ epidemiological studies of communities exposed to oil pollutants near oil fields are lacking. This is particularly true of developing countries where oil extraction is an aggressive strategy, but where impacts on the environment and population are little understood.

Oil, environment, and health in Ecuador: this study

In response to a community concern about the health effects of oil pollution, San Carlos village, which is surrounded by oil fields, was visited by one of us in October 1998. As part of a broader study of the situation, the study team found that some inhabitants mentioned the presence of several cases of cancer. These cases were attributed by local people to their continued exposure to oil pollution.

This paper reports the results of a preliminary analysis of environmental contamination of water sources, and cancer incidence and mortality in the village of San Carlos. To our knowledge, no studies about the association between oil pollutants, exposure, and cancer in residents near oil fields have previously been conducted.

\section{Population and methods}

AREA OF STUDY

San Carlos is a small village inhabited by peasants in the province of Orellana, in north eastern Ecuador. The population numbers about 1000 , most of them came to the area in the 1970 s to farm along the routes opened by the oil companies. They subsist mainly by raising cattle and involvment in other types of agriculture.

The physical infrastructure of San Carlos is poor. There is electricity but no piped drinking water or sewer services. The roads are deliberately paved with crude oil products. There is a primary health centre in the village run by a doctor and a nurse. The nearest reference centre for histopathological examinations is in Quito, $300 \mathrm{~km}$ away (12 hours by bus).

In the entrance to the village there is a large pumping station. More than 30 oil wells surround the village. Most of the oil wells are just a few meters from the houses (fig 1). The station and the wells dispose of waste, without treatment, in the small rivers that cross the village. ${ }^{40}$ These rivers are the only sources of water, and are used by the population for drinking, cooking, bathing, and washing clothes. In the pumping station, there are four powerful gas burners burning gas day and night. The oil wells in San Carlos have been in operation for more than 20 years. ${ }^{41}$ There are no chemical or other industries in the area or its surroundings.

\section{ASSESSMENT OF EXPOSURE}

Water samples from the places used by the community for drinking, bathing, and washing clothes were collected. The water was analysed for total petroleum hydrocarbons (TPHs) and was carried out by the water and soil laboratory of the P Miguel Gamboa Technical School, Coca. The TPHs were extracted with $1,1,2-$ trichlortrifluorethane and measured by infrared spectrophotometry. Special bottles for samples of water were provided by the laboratory. Laboratory technicians were kept blind to the origin of the water samples.

The main stream that crosses San Carlos is the Huamayacu river. Also, in the outskirts of San Carlos the population use the Basura, Parker, and other small rivers. During the month of March 1999 samples of the Huamayacu, Basura, Parker, and Iniap rivers were taken (one sample per river, taken close to the road). The samples were taken without visible presence of crude oil in the rivers. 
Table 1 Concentration of total petroleum hydrocarbon $(T P H) *$ in the streams of San Carlos, 1999

\begin{tabular}{ll}
\hline Stream & TPH $($ ppm $)$ \\
\hline Parker & 0.53 \\
Huamayacu & 1.444 \\
Basura & 2.883 \\
Iniap & 0.097 \\
\hline
\end{tabular}

*The permitted limit for hydrocarbons in drinking water according to the European Community laws is $0.01 \mathrm{ppm}$.

Because of economic and technical limitations it was not possible to measure land and air pollution.

\section{DATA COLLECTION}

A preliminary list of potential cancer cases from 1989 to 1998 was prepared by the health workers at the village of San Carlos. The list included the name, age, time of residence, and place of diagnosis. To confirm the diagnosis, data from the hospitals where people had been treated were solicited. Cases were included only when pathological evidence was present. No cancer registry is available in the Amazon region.

The cancers were grouped as in the 9th international classification of diseases (ICD-9).

Population data of San Carlos, stratified by age and sex, were taken from census county

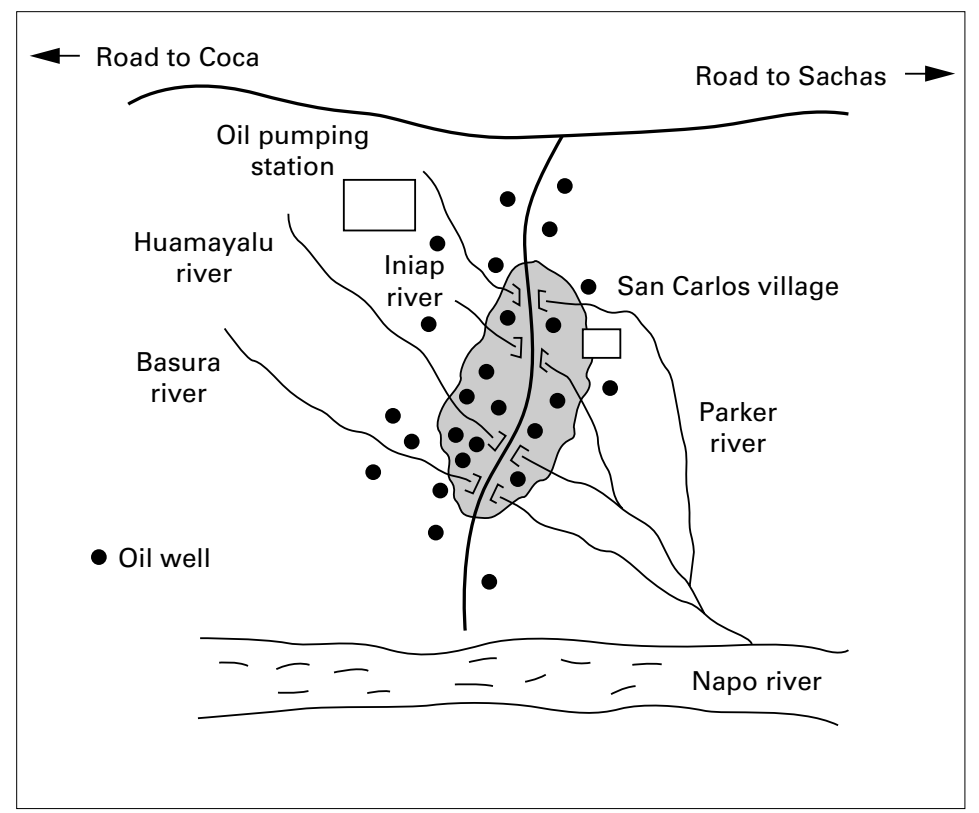

Figure 1 Map of San Carlos village and position of oil wells and rivers.

Table 2 Cases of cancer found in the village of San Carlos, Orellana, 1989-98

\begin{tabular}{lllllll}
\hline ICD-9* Sex & Type of cancer & $\begin{array}{l}\text { Date of } \\
\text { diagnoses }\end{array}$ & $\begin{array}{l}\text { Age at } \\
\text { diagnoses }\end{array}$ & Date of death & $\begin{array}{l}\text { Duration of residence } \\
\text { in San Carlos }(y)\end{array}$ \\
\hline 156 & M & Ampulla of Vater† & March 89 & 68 & July 89 & 22 \\
151 & M & Stomach & June 91 & 64 & 92 & 20 \\
151 & M & Stomach & August 92 & 55 & September 92 & 15 \\
151 & M & Stomach & June 97 & 65 & October 98 & 16 \\
161 & M & Larynx & September 97 & 46 & - & \\
155 & M & Liver & August 98 & 86 & September 98 & 26 \\
172 & M & Melanoma & Novenber 96 & 52 & August 97 & 15 \\
204 & M & Leukaemiał & July 93 & 5 & - & 7 \\
202 & F & Lymphoma $\$$ & 96 & 28 & April 99 & 16 \\
180 & F & Cervix & May 98 & 52 & - & 30 \\
\hline
\end{tabular}

${ }^{\star}$ ICD-9=ninth revision of the international classification of diseases.

tAmpulla of Vater=others and non-specific from the biliary tract.

$\ddagger$ Acute lymphoblastic leukaemia.

$§$ Non-Hodgkin's lymphom. statistics for 1998. These used the 1991 national census extrapolated to $1998 .^{42}$ Information on dates on which any individual cohort members migrated to or from the village was not available.

\section{STATISTICAL METHODS}

Statistical analysis was based on the comparison of observed and expected numbers of cancer cases; the expected numbers of deaths and cancer registrations were calculated from the incidences of the Quito reference population from 1989 to 1998, stratified by 5 year age group and sex. Quito, the capital city, is the only place in the country with an adequate cancer registry or publishing deaths by specific cause. ${ }^{43} 44$

Observed and expected values, observed/ expected ratios, and their 95\% confidence intervals (95\% CIs) based on the Poisson distribution exact method are reported.

\section{Results}

\section{EXPOSURE ASSESSMENT}

The results of the analysis of the samples taken from the rivers are presented in table 1 . In the Iniap stream, the hydrocarbon concentration was 0.09 parts per million (ppm), 0.5 in the Parker river, 1.44 in the Huamayacu, and 2.88 $\mathrm{ppm}$ in the Basura river. This compares with a permitted limit for hydrocarbons in drinking water according to the European Community laws of $0.01 \mathrm{ppm}^{45}$

\section{CANCER INCIDENCE}

The population of San Carlos was estimated to be 1000 ( 555 men and 455 women) in 1998 . Eighteen cases of cancer were identified in the preliminary list. Out of them, 10 of the patients diagnosed were resident in the village of San Carlos during the period 1989-98, and were confirmed by pathological evidence. Three were diagnosed as benign tumours and for five cases there was no access to medical records.

The characteristics of the patients and the types of cancer are presented in table 2 . Most of the cancers diagnosed were in males (8/10), three were stomach cancer. Six were diagnosed in the past 3 years. The age of diagnoses varied from 5 to 86 years. Of the 10 patients, six (all males) had already died; most of these deaths took place a short time after the diagnoses. The residence time of the patients in San Carlos was from 7 to 30 years, with a mean of 17 years.

Only one patient had worked in the oil industry, as a guardian of an oil field. From medical histories one patient was identified as a smoker.

A comparison with expected numbers, adjusted for age, is presented in table 3. An overall excess for all types of cancer was found in the male population (8 observed $v 3.5$ expected) with a risk 2.26 times higher than expected (95\% CI 0.97 to 4.46 ). No overall excess for all types of cancer was found in females ( 2 observed $v 4$ expected; $\mathrm{O} / \mathrm{E}$ ratio $0.5 ; 95 \%$ CI 0.06 to 1.80 ). 
Table 3 Cancer incidence in the village of San Carlos, 1989-98

\begin{tabular}{|c|c|c|c|c|c|c|c|c|c|}
\hline \multirow[b]{2}{*}{ Cancer } & \multirow[b]{2}{*}{$I C D-9$} & \multicolumn{4}{|c|}{ Males } & \multicolumn{4}{|c|}{ Females } \\
\hline & & $O$ & $E$ & $S I R$ & $95 \% C I$ & $O$ & $E$ & SIR & $95 \% C I$ \\
\hline All cancers $\star$ & $140-208$ & 8 & 3.53 & 2.26 & 0.97 to 4.46 & 2 & 4 & 0.5 & 0.06 to 1.80 \\
\hline Stomach & 151 & 3 & 0.64 & 4.68 & 0.95 to 13.68 & 0 & 0.36 & 0 & - \\
\hline Liver & 155 & 1 & 0.06 & 16.66 & 0.41 to 92.83 & 0 & 0.05 & 0 & - \\
\hline Ampulla of Vater† & 156 & 1 & 0.05 & 20.0 & 0.50 to 111.40 & 0 & 0.05 & 0 & - \\
\hline Larynx & 161 & 1 & 0.03 & 33.33 & 0.83 to 185.66 & 0 & 0.004 & 0 & - \\
\hline Melanoma & 172 & 1 & 0.06 & 16.66 & 0.41 to 92.83 & 0 & 0.06 & 0 & - \\
\hline Leukaemiał & 204 & 1 & 0.37 & 2.70 & 0.06 to 15.05 & 0 & 0.26 & 0 & - \\
\hline Lymphoma\$ & 202 & 0 & 0.26 & 0 & - & 1 & 0.14 & 7.14 & 0.17 to 39.78 \\
\hline Cervix & 180 & 0 & - & 0 & - & 1 & 0.43 & 2.32 & 0.05 to 12.95 \\
\hline Others & & 0 & 2.06 & 0 & - & 0 & 2.65 & 0 & - \\
\hline
\end{tabular}

*All cancers excluding non-melanoma skin cancer.

†Ampulla of Vater $=$ others and non-specific from the biliary tract.

$\ddagger$ Acute lymphoblastic leukaemia.

$§$ Non-Hodgkin's lymphoma.

$\mathrm{O}=$ observed number of cancers; $\mathrm{E}=$ expected number of cancers; $\mathrm{SIR}=$ standardised incidence ratio $(\mathrm{O} / \mathrm{E})$.

CANCER MORTALITY

Table 4 shows the results of the mortality analysis for the 10 years. There was an overall excess of deaths for all types of cancer (6 observed $v 1.6$ expected) among the male population 3.6 times higher than the reference population (95\% CI 1.31 to 7.81 ). The excess was apparent for all sites represented, cancer of the stomach and melanoma being nominally significant $(\mathrm{p}<0.05)$. No deaths due to cancer were found in women ( 0 observed $v 1.39$ expected; 95\% CI 0 to 2.64).

\section{Discussion}

This report presents an analysis of environmental contamination and incidence and mortality of cancer (1989-98) in a village in an oil producing area of the Amazon basin of Ecuador.

The analysis of water used for drinking, washing, and bathing showed a severe exposure to TPHs by the residents of San Carlos, with samples ranging from 10 to 288 times higher than the limit permitted by the European Community regulations. These data confirm that the residents of this village are exposed to concentrations of pollutants that originated from oil activity, which considerably exceed the recognised European safety limits. Although the initial time of exposure is not known, numerous reports have stated that unregulated oil exploration has occurred in the area since the 1970s. ${ }^{211} 46-48$ In 1994, a study carried out by the Center for Economic and Social Rights ${ }^{48}$ also found highly increased concentrations of oil pollutants in the streams and rivers of the area, evidence which also supported long term exposure of the residents to these toxins. Concentrations of PAHs were 10-10 000 times greater

Table 4 Mortality from cancer in males in the village of San Carlos, 1989-98

\begin{tabular}{|c|c|c|c|c|c|}
\hline \multirow[b]{2}{*}{ Cancer } & \multirow[b]{2}{*}{$I C D-9$} & \multicolumn{4}{|c|}{ Males } \\
\hline & & $O$ & $E$ & $S M R$ & $95 \% C I$ \\
\hline All cancers ${ }^{\star}$ & $140-208$ & 6 & 1.67 & 3.59 & 1.31 to 7.81 \\
\hline Stomach & 151 & 3 & 0.36 & 8.33 & 1.69 to 24.33 \\
\hline Liver & 155 & 1 & 0.046 & 21.73 & 0.54 to 121.08 \\
\hline Melanoma & 172 & 1 & 0.014 & 71.42 & 1.78 to 397.85 \\
\hline Ampulla of Vater $\dagger$ & 156 & 1 & 0.037 & 27.02 & 0.67 to 150.54 \\
\hline Others & & 0 & 1.23 & 0 & - \\
\hline
\end{tabular}

*All cancers excluding non-melanoma skin cancer.

†Ampulla of Vater=others and non-specific from the biliary tract.

$\mathrm{O}=$ observed number of cancer deaths; $\mathrm{E}=$ expected number of cancer deaths; SMR=standardised mortality ratio of cancer $(\mathrm{O} / \mathrm{E})$. than the recommendations of the United States Environmental Protection Agency.

Also the study suggests an excess of cancers among the male population in the village of San Carlos. All specific cancer sites showed an excess. Results of overall cancer mortality were also 3.6 higher than expected among males.

Despite the excess of cancer found in San Carlos and the high exposure to oil pollutants, the attribution of causality to this association must be considered with caution. When interpreting the results, several issues should be taken into the account.

When disease in an area is studied formally solely because a cluster of disease has been perceived informally, statistical results should be interpreted very cautiously. This process has been described as the "Texas sharp-shooter's" procedure. ${ }^{49}$ However, this study was led by local concern about overall health effects of oil pollution on their communities. This concern preceded identification of a cancer cluster. Therefore, the presented data are not wholly subject to the application of Texas sharp-shooter caution, strengthening the likelihood of a real effect. However, the high risk of cancer found in the population was based on small numbers, which is reflected in the wide $95 \%$ CIs, making it difficult to reject the possibility of chance.

Several limitations in the data and methods need also to be considered. Population data relied on county census estimated from the 1991 national census. Errors in population estimates, including differential migration patterns, might bias estimates of risk. However, to avoid this bias, the population of San Carlos was overestimated and migration is considered to be low (mayor of the village, personal communication).

The completeness of the cancer registration in Quito is high, 95\%, ${ }^{44}$ but there may have been cancer cases in San Carlos that were not diagnosed, making our risk estimation conservative.

The general excess in all cancers argues against a specific toxic agent which might be expected to affect the incidence of only one or perhaps a few cancer sites. ${ }^{50}$ However, epidemiological studies have reported different types of cancer being associated with occupational or residential exposure to oil pollutants. ${ }^{17-23252629-3136375152}$ These cancers could be grouped in six systems: digestive 
(buccal cavity, pharynx, stomach, liver), respiratory (nasal cavity and lung), urinary (prostate, bladder, kidney), dermal (skin), blood (leukaemia) and others (brain, bone). In our study, all diagnosed cancers-except the cervix - can be included in these groups.

The main known risk factors for the cancer most often found, stomach, are cigarette smoking, alcohol drinking, and diet. However, none of the three patients were smokers. San Carlos has a rural population, with diet based mainly on the consumption of rice, cassava, banana, meat, and occasionally fish. No data on alcohol ingestion were available.

One possibility to explain any excess risk near an industrial source is that it reflects occupational rather than environmental factors. However, just one of the patients worked in an oil facility. There is no other industrial process in the area, apart from oil, which is suspected of entailing exposures that might cause cancer. The long duration of residence of the patients in the study area is consistent with a possible environmental carcinogen, due to the long latency time of most of the carcinogens. ${ }^{3}$

The excess of morbidity was especially strong in males and only males had died of cancer. The reasons for the higher cancer incidence and mortality in males in our study are unclear. Six of the patients (and one more deceased in April 1999) had already died; most of these deaths took place a short time after the diagnoses. These data suggest either extremely aggressive cancers or they may reflect the poor access of the population of San Carlos to ameliorative health services.

There is also an uncertainty over the comparability of the Quito population and the local population. Access to health services, and socioeconomic and other possible unmeasured factors might confound the risk estimates. For some cancers - such as cancer of the larynx and skin melanoma-there is the added problem of possible residual socioeconomic confounding which could not be measured due to the lack of data.

In summary, there is evidence of severe contamination of water sources and apparent excess of cancer morbidity and mortality in the village of San Carlos. The excess of cancer could be linked, as local people suspect, to the pollution of the environment by toxic contaminants coming from oil production. Further research is necessary to obtain information on the extent of exposure of these populations to environmental contamination through water, soil, and air. Evidence is also needed on risk factors that could be producing the potentially high rates of cancer found in this population and on other populations similarly exposed. We recommend an environmental monitoring system to assess, control, and assist in elimination of sources of pollution in the area, and a surveillance system to gain knowledge of the evolution of cancer incidence and distribution in the area. We are also concerned that, despite the economic gains brought to Ecuador as a whole by the oil industry, the people who live alongside the process may experience problems as a result of the practice, and few of the benefits. This work was funded by Medicus Mundi Gipúzkoa. We thank
to the community of San Carlos for their collaboration and to Janet Andrade and Dr Pepe Yépez for their support.

1 Jochnick C, Normand R, Zaidi S. Rights violations in the Ecuadorian Amazon: the human consequences of oil Ecuadorian Amazon: the human consequences

2 Kimerling J. Amazon crude. New York: Natural Resources Defence Council, 1991.

3 International Agency for Research on Cancer. Monographs on the evaluation of the carcinogenic risk of chemicals to man: occupational exposures to petroleum refining; crude oil and major petroleum fuels. Vol 45. Lyon, France: IARC, 1989

4 Grimmer G, Dettbarn G, Brune H, et al. Quantification of the carcinogenic effect of polycyclic aromatic hydrocarbons in used engine oil by topical application onto the skin of mice. Int Arch Occup Environ Health 1982;50:95-100.

5 Clark CR, Walter MK, Ferguson PW, et al. Comparative dermal carcinogenesis of shale and petroleum-derived distillates. Toxicol Ind Health 1988;4:11-22.

6 Wilson JS, Holland LM. Periodic response difference in mouse epidermis chronically exposed to crude-oils or BaP: males $v$ females. Toxicology 1988;50:83-94.

7 Wong O. An industry wide mortality study of chemical Wong $\mathrm{O}$. An industry wide mortality study of chemical
workers occupationally exposed to benzene. I. General workers occupationaly exposed to

8 Austin H, Delzell E, Cole P. Benzene and leukaemia: a review of the literature and a risk assessment. Am F Epidemiol 1988;127:419-39.

9 Hayes RB, Yin SN, Dosemeci M, et al. Benzene and the dose-related incidence of hematologic neoplasms in China. f Natl Cancer Inst 1997;89:1065-71.

10 Savitz DA, Andrews KW. Review of epidemiologic evidence on benzene and lymphatic and hematopoietic cancers. $\mathrm{Am}$ f Ind Med 1997;31:287-95.

11 Campbell D, Cox D, Crum J, et al. Initial effects of the grounding of the tanker Braer on health in Shetland. BMF 1993;307:1251-5.

12 Gerin M, Siemiatycki J, Desy M, et al. Associations between several sites of cancer and occupational exposure to benzene, toluene, xylene, and styrene: results of a
case-control study in Montreal. Am f Ind Med 1998;34: case-control

13 Fagliano J, Berry M, Bove F, et al. Drinking water contamination and the incidence of leukemia: an ecologic study. nation and the incidence of leukemia:

14 Everall JD, Dowd PM. Influence of environmental factors excluding ultra violet radiation on the incidence of skin cancer. Bull Cancer 1978;65:241-7.

15 International Agency for Research on Cancer. Monographs on the evaluation of the carcinogenic risk of chemicals to man: polynuclear aromatic hydrocarbons. Vol 34. Lyon, France: IARC, 1983.

16 Bonassi S, Merlo F, Pearce N, et al. Bladder cancer and occupational exposure to polycyclic aromatic hydrocarbons. Int $\mathcal{f}$ Cancer 1989;44:648-51.

17 Mastrangelo G, Fadda E, Marzia V. Polycyclic aromatic hydrocarbons and cancer in man. Environ Health Perspect 1996;104:1166-70.

18 Boffetta P, Jourenkova N, Gustavsson P. Cancer risk from occupational and environmental exposure to polycyclic aromatic hydrocarbons. Cancer Causes Control 1997;8:444-
ard 72 .

19 Nadon L, Siemiatycki J, Dewar R, et al. Cancer risk due to occupational exposure to polycyclic aromatic hydrocarbons. Am f Ind Med 1995;28:303-24.

20 Kaldor J, Harris JA, Glazer E, et al. Statistical association between cancer incidence and major-cause mortality, and estimated residential exposure to air emissions from petroleum and chemical plants. Environ Health Perspect 1984;54: 319-32.

21 Blot WJ, Brinton LA, Fraumeni JF, et al. Cancer mortality in US counties with petroleum industries. Science 1977;198: $51-3$.

22 Gottlieb MS, Shear CL, Seale DB. Lung cancer mortality and residential proximity to industry. Environ Health Perspect 1982;45:157-64.

23 Olin RG, Ahlbom A, Lindberg-Navier I, et al. Occupational factors associated with astrocytomas: a case-control study. Am f Ind Med 1987;11:615-25.

24 Hearey CD, Ury H, Siegelaub A, et al. Lack of association between cancer incidence and residence near petrochemibetween cancer incidence and residence near petrochemical industry in the Sa

25 Knox EG, Gilman EA. Hazard proximities of childhood cancers in Great Britain from 1953-80. F Epidemiol Community Health 1997;51:151-9.

26 Knox EG, Gilman EA. Migration patterns of children with cancer in Britain. $\mathcal{F}$ Epidemiol Community Health 1998;52: 716-26.

27 Lyons RA, Monaghan SP, Heaven M, et al. Incidence of leukaemia and lymphoma in young people in the vicinity of the petrochemical plant at Baglan Bay, South Wales, 197491. Occup Environ Med 1995;52:225-8.

28 Wilkinson $\mathrm{P}$, Thakrar B, Walls $\mathrm{P}$, et al. Lymphohaematopoietic malignancy around all industrial complexes that include major oil refineries in Great Britain. Occup Environ Med 1999;56:577-80.

29 Yang CY, Chiu HF, Chiu JF, et al. Cancer mortality and residence near petrochemical industries in Taiwan. $f$ Toxicol Environ Health 1997;50:265-73.

30 Yang CY, Cheng MF, Chiu JF, et al. Female lung cancer and petrochemical air pollution in Taiwan. Arch Environ Health 1999;54:180-5. 
31 Pan BJ, Hong YJ, Chang GC, et al. Excess cancer mortality among children and adolescents in residential districts polluted by petrochemical manufacturing plants in Taiwan. $\mathcal{F}$

32 Mills PK, Newell GR, Johnson DE. Testicular cancer associated with employment in agriculture and oil and natura gas extraction. Lancet $1984 ; \mathrm{i}: 207-10$

33 Sewell CM. Castle SP, Hull HF, et al. Testicular cancer and employment in agriculture and oil and natural gas extraction. Lancet 1986;i:553.

34 Siemiatycki J, Dewar R, Nadon L, et al. Associations between several sites of cancer and 12 petroleum-derived liquids. Results from a case-referent study in Montreal. Scand 7 Work Environ Health 1987;13:493-504.

35 Divine BJ, Barron V. Texaco mortality study III. A cohort study of producing and pipeline workers. Am f Ind Med 1987;11:189-202.

36 Sathiakumar N, Delzell E, Cole P, et al. A case-control study of leukemia among petroleum workers. 7 Occup Environ of leukemia among petro

37 Yang C, Zhang X. Incidence survey of leukemia in China. Chin Med Sci f 1991;6:65-70.

38 Palinkas LA, Petterson JS, Russell J, et al. Community patterns of psychiatric disorders after the Exxon Valdez oil spill. Am F Psychiatry 1993;150:1517-23.

39 Lyons RA, Temple MF, Evans D, et al. Acute health effects of the Sea Empress oil spill. I Epidemiol Community Health 1999;53:306-10.

40 Talbot D. Rain forest pays the price of oil: suit claims Texaco polluted Ecuador. Boston, MA, USA: Boston Herald, August 29,1999

41 Garzón P. Impacto socioambiental de la actividad petrolera: estudio de caso de las comunidades San Carlos y La Primavera (Socio-environmental impact of oil development: case study of San Carlos and La Primavera communities). In: Varea A Ortiz P. Marea negra en la Amazonia: conflictos socioambientales vinculados a la actividad Amazonia:confictos socioambientales vinculados a la actividar
42 Instituto Nacional de Estadísticas y Censos. Cifrando y descifrando Napo (Ciphering and deciphering Napo). Quito: Instituto Nacional de Estadísticas y Censos, 1995.

43 Parkin DM. Cancer incidence in five continents. Lyon, France: International Agency for Research on Cancer, 1997.

44 Sociedad de Lucha contra el Cáncer. Cáncer en Quito; anuario 1995-6 (Cancer in Quito; annual report 1995-6). Quito: Sociedad de Lucha contra el Cáncer, 1998.

45 Zehner R, Villacreces LA. Estudio de la calidad de aguas de río en la zona de amortiguamiento del Parque Nacional Yasuni. Primera fase: monitoreo de aguas - screening Octubre de 1997 Study of the water quality in the proximity to the Yasuni National Park. First phase: water screening October 1997). Coca, Ecuador: Laboratorio de Aguas y Suelos P Miguel Gamboa-Fepp, 1998.

46 Dirección General de Medioambiente. Estudio de impacto ambiental 42 (Environmental impact assessment 42). Quito: Dirección General de Medioambiente, 1989.

47 Kimerling J. Rights, responsibilities, and realities: environmental protection law in Ecuador's Amazon oil fields. mental protection law in Ecuador's Amazon oil fields. 2:293-384.

48 Centro para Derechos Económicos y Sociales. Violaciones de derechos en la Amazonía Ecuatoriana (Human rights violations in the Amazon basin of Ecuador). Quito: Abya-Yala, 1994.

49 Rothman KJ. A sobering start for the cluster busters' conference. Am f Epidemiol 1990;132(suppl 1):6S-13S.

50 Wilkinson $P$, Thakrar B, Shaddick G, et al. Cancer incidence and mortality around the Pan Britannica Industries pesticide factory, Waltham Abbey. Occup Environ Med 1997;54:101-7.

51 Seidler A, Heiskel H, Bickeboller R, et al. Association between diesel exposure at work and prostate cancer. Scand 7 Work Environ Health 1998;24:486-94.

52 Krstev S, Baris D, Stewart PA, et al. Risk for prostate cancer by occupation and industry: a 24 state death certificate study. Am F Ind Med 1998;34:413-20.

\section{1st Asia Pacific Forum on Quality Improvement in Health Care. Three day conference}

\section{Wednesday 19 to Friday 21 September 2001 Sydney, Australia}

We are delighted to announce this forthcoming conference in Sydney.

Delegate enquiries are welcome.

The themes of the Forum are:

- Improving patient safety

- Leadership for improvement

- Consumers driving change

- Building capacity for change: measurement, education, and human resources

- The context: incentives and barriers for change

- Improving health systems

- The evidence and scientific basis for quality improvement.

Presented to you by the BMJ Publishing Group (London, UK) and Institute for Healthcare Improvement (Boston, USA), with the support of the the Commonweatlh Department of Health and Aged Care (Australia), Safety and Quality Council (Australia), NSW Health (Australia), and Ministry of Health (New Zealand).

For more information contact: quality@bma.org.uk or fax +44(0) 73836869 